\title{
An Analysis of the Ruling Experience of the Communist Party of China in the Past 70 Years
}

\author{
Ning Liu \\ School of Marxism \\ Xi'an Medical University \\ Xi'an, China 710021
}

\begin{abstract}
In the past 70 years since the founding of the People's Republic of China, the Chinese Communist Party has formulated a series of major strategic measures, issued a series of major policies and principles, and promoted a series of major tasks based on the party's conditions, national conditions, world conditions, and the people's conditions to guide the socialist revolution and engage in the long-term development and reform. It has achieved remarkable development achievements and accumulated a large number of leadership experiences and ruling experience. These ruling experiences include: always adhering to the guiding position of Marxism, firmly grasping the dominance of ideology, always adhering to the people-centered to ensure the party's value orientation that builds the party for the public and the government for the people, always adhering to the integration of ideological party building and institutional party governance, believing the ideals and beliefs, building a systemic barrier, always adhering to the anti-corruption construction, and maintaining the advanced nature and purity of the party. On the occasion of the 70th anniversary of the founding of the People's Republic of China, the exploration and summarization of the valuable leadership experience and ruling experience of the Communist Party of China have vital and far-reaching influence on improving the Chinese Communist Party's ability to govern the country, consolidating the legitimacy of the regime, and unifying the great struggle, great project, great cause and great dream.
\end{abstract}

Keywords - the Communist Party of China; the ability to govern; governing experience; the great dream

\section{INTRODUCTION}

The Party exercises overall leadership over all areas of endeavor in every part of the country. History and practice have repeatedly proved that the leadership of the ruling party is crucial to national liberation, people's happiness, and national development. History serves as the best lesson book and the best dose of sobriety. In the early 1990s, the collapse of the Soviet Union and the drastic changes in Eastern Europe resulted from complicated and diverse reasons, but the absence of correct leadership with the ruling party was also a very important factor. If the ruling party wants to avoid the historical cycle and hold the political power well and build it well, it must be advancing with the times, blazing new trails in a pioneering spirit, constantly drawing lessons and summarizing experience. In the past 70 years since the founding of the People's Republic of China, the Communist Party of China, the core force leading China's cause, has always attached great importance to historical experience summarized from practice and creative spirit. During the new-democratic revolution, the Communist Party of China led the Chinese people to complete the newdemocratic revolution, overthrew the oppression of the three mountains: imperialism, feudalism and bureaucrat-capitalism, and realized the people's liberation and national independence. During the socialist revolution, the Communist Party of China led the people of all ethnic groups to complete the socialist revolution. The basic system of socialism was established. During the period of socialist construction, the Communist Party of China led the Chinese people to successfully open up the road of socialism with Chinese characteristics, and actively planned the great cause, great project, great dream, and great struggle of socialism with Chinese characteristics. Without the Communist Party of China, there would be no People's Republic of China. Therefore, the leadership of the Communist Party of China can stand the test of practice and the people, is in favor of the general public, and is the conscious and voluntary choice made by the Chinese people in conformity with the laws and logics of historical development and based on historical necessity.

\section{THE COMMUNIST PARTY OF CHINA Always} ADHERES TO THE GUIDING POSITION OF MARXISM

General Secretary Xi Jinping mentioned in his speech at the 2013 National Promotion Work Conference: "Ideological work is an extremely important work of the Communist Party of China, which is related to the future and destiny of the party, to the long-term stability of the country, to the national cohesiveness and centripetal force". The guiding position of Marxism in the field of ideology is the inevitable choice of the Chinese people in the process of national salvation. Marxism is a scientific theory about the general laws of nature, society and human development, and a powerful ideological weapon for understanding the world and transforming the world. "The correct theory must be clarified and used in accordance with the existing conditions and specific circumstances." At the beginning of the 19th century, China was torn apart by wars, facing internal and external "troubles". The October Revolution (1917) sent Marxism to China. Mao Zedong Thought, the crystallization 
of collective wisdom, was produced through the combination of Marxism and reality of the Chinese revolution. They two both contributed much to the victory of the new democratic revolution. In the early stage of People's Republic of China, Mao Zedong emphasized: "The Communist Party of China has a history of 28 years. It's widely known that the past years was not in peace, but was very difficult and challenging, as it's a must to combat against enemy both in home and abroad." Thanks to Marx, Engels, Lenin and Stalin, Chinese obtained the weapons needed. The weapon here is not a machine gun, but Marxism and Leninism. After the founding of the People's Republic of China, the Party Central Committee initiated the call for studying Marxism and Mao Zedong Thought, and promoted Marxism through the improvement of the party organizations at all levels, and newspapers, reading clubs, radio, film and other forms; compiled the "Selected Works of Mao Zedong" to constantly struggle with various wrong thoughts inside and outside the Party, and properly handle contradictions of different natures. Marxism is a theory of constant development and change. During the period of reform and opening up, the secondgeneration central collective leadership of the Communist Party of China with Deng Xiaoping as the core not only inherited and developed Mao Zedong Thought, founded Deng Xiaoping Theory, but also played a foundational and pioneering role in the theoretical system of socialism with Chinese characteristics; answered the fundamental question of what is socialism and how to build socialism, and profoundly revealed the essence of socialism; A great turning point in the history of the development of the Chinese nation and a landmark decision was made - reform and opening up. He resolutely opposed and corrected the wrong ideas of "left" and "right", and opposed bourgeois liberalization. He also clearly pointed out that "It's needed to criticize the wrong ideas of "left" and "right. The modernization of China does not necessarily mean liberalization, and we Chinese should never follow the Western capitalist path. The thirdgeneration central collective leadership of the Communist Party of China with Jiang Zemin as the core put forward "three emphases education": to stress theoretical study, political awareness and good conduct, answer the question that "what kind of party is being built, how to build the party". The Party Central Committee with Comrade $\mathrm{Hu}$ Jintao as general secretary holds high the great banner of socialism with Chinese characteristics and answers the question of "what kind of development and how to develop it" based on the reality that China is and will be in the primary stage of socialism. Since the 18th National Congress of the Communist Party of China, the Party Central Committee with comrade Xi Jinping as the core has enriched and developed the theoretical achievements of sinicization of Marxism, opened up a new realm of sinicization of Marxism, and answered the questions of the times about what kind of socialism with Chinese characteristics should be adhered to and developed in the new era and how to uphold and develop socialism with Chinese characteristics, thus forming $\mathrm{Xi}$ Jinping Thought on Socialism with Chinese Characteristics for a New Era, which is the latest theoretical form of Marxism in the 21st century. It embodies the organic combination of Marxism and China's concrete reality and continuously promotes the sinicization of Marxism. "In contemporary China, to uphold $\mathrm{Xi}$ Jinping Thought on Socialism with Chinese Characteristics for a New Era is to truly uphold Marxism." The report of the 19th National Congress of the Communist Party of China mentioned: "It's a must to promote the Chinization, modernization and popularization of Marxism, and build a socialist ideology with strong cohesiveness and leadership." Therefore, it is necessary to promote the sinicization of Marxism, make Marxism deeply rooted in China and firmly grasp the guiding position of Marxism in ideology.

\section{THE COMMUNIST PARTY OF CHINA AlWAYs} ADHERES TO THE PEOPLE-CENTERED RULING PHILOSOPHY, AND ENSURES THE VALUE ORIENTATION OF GOVERNANCE

Marx criticized Bruno Powell and other Hegelians' idealistic views of history and other false theories about the masses of the people, and put forward the historical viewpoint of the masses. He believed that the masses of the people are the driving force of social development and the creators of material and spiritual wealth. It's possible to regard this as the value orientation and class position of the proletariat to guide the revolutionary struggle of the proletariat for human liberation. He pointed out: "Historical activities are the cause of the masses. The deepening of historical activities is bound to be the expansion of the masses." "If people absolutely criticize and condemn an object as "superficial," then this object is the whole history to date, for the activities and thoughts of history are the thoughts and activities of the 'masses'". Marxism has distinct class nature and practicality. Since its birth, Marxism has made it clear that it serves the proletariat and the masses, serves the liberation of all mankind and firmly believes that capitalism will inevitably perish and socialism will inevitably win. The Communist Party of China adheres to the principle of serving the people wholeheartedly; insists on the party's value orientation and governing idea that builds the party for the public and the government for the people; follows the mass line that doing everything for the masses, relying on them in every task, carrying out the principle of "from the masses, to the masses"; and sticks to the principle that the government must empathize with the feelings of the people, and work for the well-being of the people. This is a panel feature of Marxist parties that distinguish them from other political parties. Follow your original aspiration and you will succeed. The initial heart and mission of Communist Party of China is to seek happiness for the Chinese people and seek rejuvenation for the Chinese nation. The first-generation central collective leadership of the Communist Party of China with Comrade Mao Zedong as the core has established a broad revolutionary united front and fully recognized the importance of the people for the Chinese revolution. He pointed out: "The real impregnable fortress is the masses. It is the millions of people who really support the revolution. This is the real impregnable fortress that can't be broken by any force." "The masses are real heroes, and our members are often naive and ridiculous. Without knowing this, it's impossible to obtain the minimum knowledge." The second-generation central collective leadership of the Communist Party of China with Comrade 
Deng Xiaoping as the core put forward The "three favorable" standards: whether it is conducive to developing the productive forces of the socialist society, whether it is conducive to enhancing the comprehensive national strength of the socialist country, and whether it is conducive to improving the living standards of the people. This is an important criterion for judging the success of the socialist cause. He proposed that the essence of socialism is to liberate and develop productive forces, eliminate exploitation and polarization, and finally achieve common prosperity. He advocated the implementation of the household contract responsibility system, and demanded that the party must regard the people's thinking and thoughts as the starting point and destination for formulating various principles and policies. The third-generation central collective leadership of the Communist Party of China with Jiang Zemin as the core put forward the "three represents" important thought and stressed that it is necessary to give full play to the advantages of the masses. The leadership and all work of the party must rely on the people, believe in the people, draw on the wisdom of the people, respect the creation of the people, and accept the supervision of the people". "Only the people are the supreme arbitrators of the value of our work." He emphasizes the need to balance efficiency and fairness. The Party Central Committee with Comrade Hu Jintao as general secretary insist on building the party for the public and the government for the people, and stress the importance of studying dialectical materialism and historical materialism to deepen the Party's understanding of mass viewpoint and mass line. It's a must to fully and correctly implement the party's line, principles, and policies, be good at proceeding from the local realities, do a good job in mobilizing and guiding the masses, care about the lives of the people, and effectively solve practical problems for the masses; as well as improve the ability to correctly handle the contradictions among the people. Since the 18th National Congress of the Communist Party of China, the Party Central Committee with Comrade Xi Jinping as its core has respected the people, relied on the people, affirmed the people, and always seeks happiness and rights for the people. He pointed out that the people are the creators of history and the people are true heroes. In his speech at the Spring Festival party in 2019, he pointed out: "I said in this year's New Year speech that the people are the greatest strength of our ruling. All achievements in the development of the cause of the party and China are attributed to the people. As long as we rely on the people, there will be no difficulties and obstacles that cannot overcome, and there will be no great achievements that cannot be made." Whether in economy, politics, news propaganda work, cyber security and IT application, issues concerning agriculture, rural areas and farmers, etc., it is a must to carry out the people-centered development ideology, ensure and improve people's livelihood on the issues that people care most about, and promote social fairness and justice. It will enable children have access to instruction, students to education, employees to pay, patients to medical treatments, elders to good care, residents to housing, and the vulnerable to help, and constantly enhance the people's sense of acquisition, happiness and security.
IV. The COMMUNist PARTY OF CHINA AlWAYS ADHERES TO THE INTEGRATION OF IDEOLOGICAL PARTY BUILDING AND INSTITUTIONAL PARTY GOVERNANCE, STRENGTHENS THE IDEALS AND BELIEFS, AND BUILDS A SYSTEMIC BARRIER

Ideological party building and institutional party governance is the fine traditions and political advantages of the Communist Party of China. It is an important way for the party to play its leadership and to continuously improve the advanced nature and purity of the party. System is a rigid provision with coercive force, binding force and normativeness. Ideological party building and institutional party governance has a long history in the history of the Communist Party of China. During the revolutionary period, the Chinese Communists carried out preliminary explorations on ideological party building and institutional party governance, and continued to develop and improve during the construction period. The first-generation central collective leadership of the Communist Party of China with Comrade Mao Zedong as the core has established an ideological line of seeking truth from facts, carried out a rectification movement, and strengthened ideological education. At the beginning of the "Gutian Congress Resolution", Mao Zedong pointed out the serious harm of various mistaken ideas for our army and our party and proposed specific correction methods. For example, in the case of individualism, it is necessary to strengthen education and correct individualism in terms of ideology. One of the methods mentioned in Gutian Congress Resolution to solve the remnant of putschism is to "eliminate putschism from the ideology". As regards to remnants of putschism, it is a must to "correct the act of moving blindly from institutional and policy". As regards to a purely military point of view, the Gutian Congress Resolution stated: "The Red Army regulations should be formulated to clearly define the tasks of the Red Army, the relationship between the military work system and the political work system, the relationship between the Red Army and the people, the power of the soldiers' association and its relationship with the military political organs". The second-generation central collective leadership of the Communist Party of China with Comrade Deng Xiaoping as the core attaches importance to the legalized society, values system construction, bring order out of ideological chaos, and promotes efforts to enforce strict Party discipline. He pointed out: "Ideological construction serves as the forerunner of party building. After the party's leadership issue has been strengthened and improved, party members should also follow up the pace of education and must not relax at all times to build a stronger internal structure of party members." The third-generation central collective leadership of the Communist Party of China with Jiang Zemin as the core advocates that the Party supervises its own conduct and enforces strict discipline, and strengthen the ideological party building. The Party Central Committee with Comrade $\mathrm{Hu}$ Jintao as general secretary emphasizes strengthening the party's ideological and political work. Since the 18th National Congress of the Communist Party of China, the Party Central Committee with Comrade Xi Jinping as its core has attached great importance to the unity of ideological party building and institutional party 
governance, emphasized the importance of ideals and beliefs with calcium and proposed that: "The Party Constitution is the general charter and general rules; "The party should be governed by institutions and rules", and "Confining power to an institutional cage", to clarify that the enforcement of strict Party discipline must be in line with institutional governance. In the new era, some party members have experienced phenomena such as lack of energy, extravagance, hedonism, individualism, and weak ideals and beliefs. There are both international factors and domestic factors. On the one hand, with the growing development of economic globalization and political multi-polarization, the Communist Party of China is facing an increasingly severe test of the external environment. Western countries strive to import and infiltrate Western ideology into China with an excuse of "cyber freedom" and through vigorously rendering "China threat theory". Thus, various non-Marxist thoughts are constantly pouring into China, greatly affecting the thinking of party members; on the other hand, with the dominant position of the market economy, the development of economy is promoted, while at the same time, money worship, trade power for money and hedonism are emerging. Faced with such a severe and complex environmental, it is especially important to insist on ideological party building. Therefore, it's a must to place Marxist ideals and beliefs education in an important position, systematically grasp the basic theory of Marxism and regard it as a special and indispensable skill, understand the Party Constitution and the history of the party to enhance historical memory and patriotism; secondly, it's a must to proceed from reality, integrate theory with practice, seeks truth from facts, tests and develops truth in practice, and oppose the misconceptions that ignores the connection between subjective and objective elements. Therefore, in the process of implementation, it's a must to actively understand the specific situation, listen to opinions and suggestions at all levels, rely on people's wisdom, and collect public opinions. Since the 18th National Congress of the Communist Party of China, the Communist Party of China has faced a more complicated ruling environment and is facing "four dangers and four tests". To promote the modernization of the national governance system and governance capacity, it is necessary to establish strict rules and regulations within the party and adhere to it. That is, the Communist Party of China participate in and manage various affairs within the party through various forms in accordance with the rules and regulations of the Party Constitution under the strong leadership of the Party Central Committee with Comrade Xi Jinping as its core, and ensure all work can be carried out in accordance with the rules, gradually realize the institutionalization and standardization of intra-party democracy, and make the party's internal laws and regulations be adheres to by all party members including the leaders, and constantly make clear the party's discipline and consciously safeguard the unity within the party. It's needed to resolutely oppose sectarianism and individualism, and adhere to the principle of democratic centralism. The close the integration of ideological party building and institutional party governance is the new strategy to ensure that the Party supervises its own conduct and enforces strict discipline. It is a great exploration of the party building law of the
Communist Party of China, a profound summary of the party building history of the Communist Party of China, and a prerequisite for the Communist Party of China to make selfpurification, self-perfection, self-innovation, and selfimprovement. The ideological party building and institutional party governance complement each other and are closely linked. The former serves as guidance for that latter, while the latter provides a reliable guarantee for the former.

\section{CONCLUSION}

During the past 70 years since the founding of the People's Republic of China, the Communist Party of China enriched and developed the Marxist theory of the construction of the ruling party, and always adhered to the unity of theoretical innovation and practice innovation, constantly learning lessons and summing up experience. The Communist Party of China played a key role in advancing the China's revolution and construction. Through joint participation and planning, the CPC has concentrated its efforts on solving many difficult problems that it had long wanted to solve but had not solved, and accomplished many great things that it had long wanted to accomplish but had not accomplished. Historic changes have taken place in the cause of the party and China. History and practice have repeatedly proved that the ruling party can only bear the heavy responsibility and mission entrusted to the party by the times and the people only by adhering to the theoretical quality of advancing with the times, persisting in the concept of innovation and development, and repeatedly testing in the process of continuous practice and governance. Adhering to seeking truth from facts and starting from reality, testing and developing truth in practice is not only the most important theoretical quality of Marxism, but also the ideological line of the Communist Party of China. The ruling experience of the Communist Party of China is the wisdom of China and important experience accumulated and gained through the exploration of Chinese people of all ethnic groups led by generations of collective leaders in the process of China's revolution, construction, and reform. The ruling status of the Communist Party of China is an inevitable choice and can stand the test of practice, people, times, and development. In the new era, it is a must to adhere to Xi Jinping Thought on Socialism with Chinese Characteristics for a New Era, always adhere to the guiding position of Marxism, always adhere to the development ideology centered on the people, maintain the flesh-and-blood ties with the people, and always adhere to the integration of ideological party building and institutional party governance, and always adhere to the anticorruption construction. In the new era, adhering on the ruling experience is of important theoretical and practical significance for the Communist Party of China to promotes the "four comprehensive" strategic layout, profoundly understands the "four tests, four dangers" faced by the party, strengthen the ability to govern, deeply explore the law of governance and social development, capture the great victory of socialism with Chinese characteristics in the new era, and realize the great rejuvenation of the Chinese nation. 


\section{REFERENCES}

[1] The Complete Works of Marx and Engels (Vol. 1) [M]. Beijing: People's Publishing House, 2004. (in Chinese)

[2] The Complete Works of Marx and Engels (Vol. 47) [M]. Beijing: People's Publishing House, 2004. (in Chinese)

[3] Selected Works of Mao Zedong (Vol. 2) [M]. Beijing: People's Publishing House, 2007. (in Chinese)

[4] Selected Works of Mao Zedong (Vol. 3) [M]. Beijing: People's Publishing House, 2007. (in Chinese)

[5] Selected Works of Mao Zedong (Vol. 4) [M]. Beijing: People's Publishing House, 2007. (in Chinese)

[6] Selected Works of Deng Xiaoping (Vol. 2) [M]. Beijing: People's Publishing House, 2001. (in Chinese)

[7] Selected Works of Deng Xiaoping (Vol. 3) [M]. Beijing: People's Publishing House, 2001. (in Chinese)

[8] Hu Jintao's Selected Works (Vol. 1) [M]. Beijing: People's Publishing House, 2016. (in Chinese)

[9] Selected Documents of Important Literature Since the Third Plenary Session of the 11th CPC Central Committee [M]. Beijing: Central Literature Publishing House, 2011. (in Chinese)

[10] Xi Jinping: The Governance of China (Vol. 2) [M]. Beijing: People's Publishing House, 2017. (in Chinese)

[11] Decisive Victory in Building a Well-off Society in an All-round Way to Win a Great Victory in Socialism with Chinese Characteristics in the New Era - Report at the 19th National Congress of the Communist Party of China [M]. Beijing: People's Publishing House, 2017. (in Chinese)

[12] Excerpts on Xi Jinping's Thoughts on the Construction of Socialist Culture [M]. Beijing: Central Literature Publishing House, 2017. (in Chinese)

[13] Selected Works of Important Documents since the Eighteenth National Congress (I) [M]. Beijing: Central Literature Publishing House, 2018. (in Chinese)

[14] Wu Dabing, Yue Qilin. The Basic Experience Analysis of Consolidating the Ruling Foundation of the CPC Since the Reform and Opening up [J]. Chongqing Social Sciences, 2017(10): 5-10. (in Chinese)

[15] The Celebration of the 40th Anniversary of Reform and Opening Up was Held in Beijing [N]. People's Daily, 2018-12-19 (01). (in Chinese)

[16] Xi Jinping Thought on Socialism with Chinese Characteristics for a New Era is a Model of Marxist Innovation and Development in the 21st Century [N]. Guangming Daily, 2018-12-28 (06). (in Chinese)

[17] Speech at the Spring Festival Group Meeting in 2009 [N]. People's Daily, 2019-02-04 (01). (in Chinese) 